
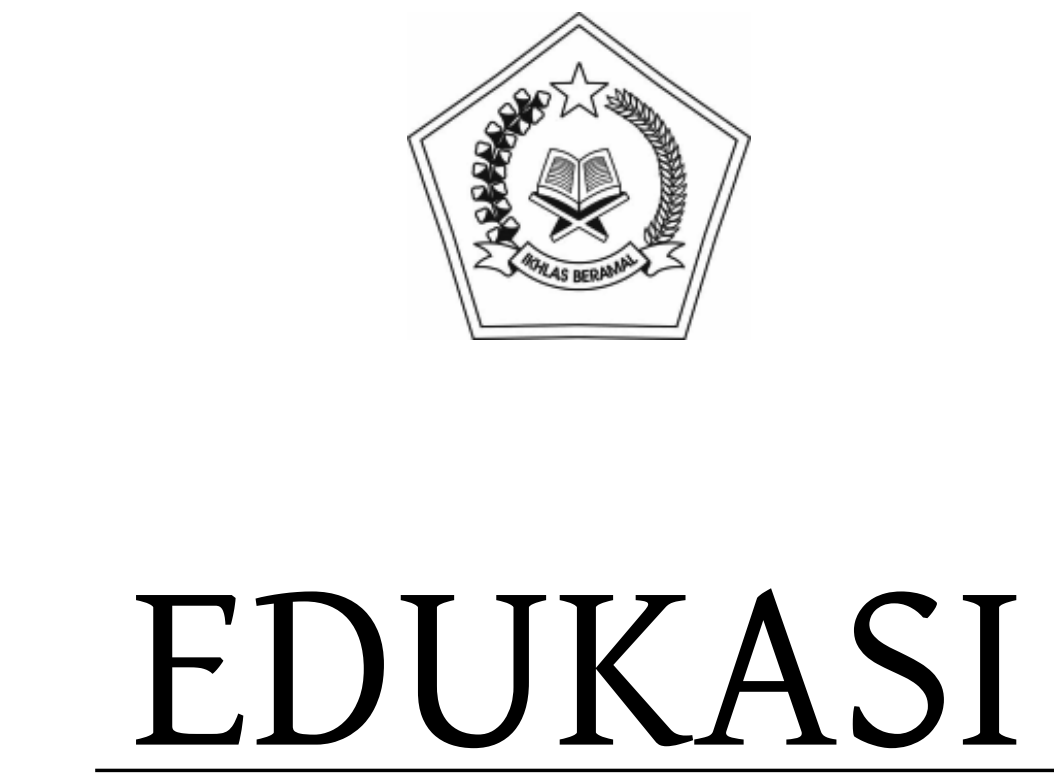

JURNAL PENELITIAN PENDIDIKAN AGAMA DAN KEAGAMAAN

VOLUME 13, NOMOR 3, DESEMBER 2015 


\title{
PENGARUH IMPLEMENTASI PENDIDIKAN AGAMA TERHADAP PERILAKU KEAGAMAAN PESERTA DIDIK SMA DI BAWAH YAYASAN KEAGAMAAN
}

Studi Kasus di SMA Muhammadiyah 1 dan

SMA Kristen Palangkaraya

\author{
THE INFLUENCE ON EDUCATIONAL \\ IMPLEMENTATION AGAINST RELIGIOUS BEHAVIOR \\ OF SENIOR HIGH SCHOOL (SMA) STUDENT: UNDER \\ RELIGIOUS FOUNDATION
}

\author{
Case Study at SMA Muhammadiyah 1 and \\ SMA Kristen Palangkaraya
}

Lilam Kadarin Nuriyanto

Balai Penelitian dan Pengembangan Agama Semarang

Jl. Untung Suropati Kav. 70 Ngaliyan Semarang

Email : lilam_ltbg@yahoo.com

Naskah diterima 9 September 2015, direvisi 8 Desember 2015, disetujui 10 Desember 2015

\begin{abstract}
This research is carried out at SMA Kristen Palangkaraya and Muhammadiyah 1 Palangkaraya. The research aims at finding out implementation of religious education curriculum that has been applied for the school under religious foundation and its influence against religious behavior of the student which is seen from the aspect of religiosity, honesty, tolerance, reconciliation, social awareness and ideal form in the implementation. Method applied in this research is combination between quantitative and qualitative approach using focus group discussion (FGD). The influence of relation of $r 2$ (determination coefficient) is around 0.343. It means that a religious behavior of the student is $34,3 \%$ that can be explained by the religious education implementation and remaining $65.7 \%$ should be explained by other factors. The FGD is to find out an idea in building the student character in the expectation of building religious spiritual (religious aspect) and social piety (aspects of honesty, tolerance, love peace and social preservation).
\end{abstract}

Keyword : religious education, behavior, religiosity student
Abstrak

Penelitian ini dilakukan di SMA Kristen Palangkaraya dan Muhammadiyah 1 Palangkaraya. Penelitian ini bertujuan untuk mengetahui pelaksanaan kurikulum pendidikan agama yang telah diterapkan untuk sekolah di bawah yayasan keagamaan, dan pengaruhnya pada perilaku keagamaan peserta didik dilihat dari aspek religiusitas, kejujuran, toleransi, perdamaian, kesadaran sosial, dan bentuk yang ideal dalam pelaksanaannya. Metode yang dipakai pada penelitian ini adalah kombinasi antara pendekatan kuantitatif dan kualitatif yang menggunakan focus group discussion (FGD). Besarnya pengaruh hubungan dari r2 (koefisien determinasi) adalah sekitar 0.343. Artinya, perilaku keagamaan siswa sebesar 34,3\% dapat dijelaskan oleh pelaksanaan pendidikan agama, dan sekitar 65,7\% yang tersisa harus dijelaskan oleh faktor lain. Melalui FGD untuk menemukan ide dalam membangun karakter siswa dengan harapan membangun spiritual keagamaan (aspek religius) dan kesalehan sosial (aspek kejujuran, aspek toleransi, aspek cinta damai, dan aspek perawatan sosial).

Kata Kunci : pendidikan agama, perilaku, keagamaan siswa 


\section{PENDAHULUAN}

Dampak negatif perubahan sosial akibat modernisasi dan globalisasi di antaranya adalah perubahan pola hidup ke arah yang lebih konsumtif, dimana perubahan sikap hidup masyarakat yang lebih individualistik. Hal ini karena merasa dipermudah dengan kemajuan teknologi dalam memenuhi kebutuhannya, sehingga merasa tidak lagi membutuhkan orang lain. Sehingga ada indikasi manusia terkadang lupa menjadi bagian sosial yang saling membutuhkan antara satu dengan lainnya. Sedangkan dampak negatif terhadap sikap siswa adalah sudah berkurang rasa hormat kepada orang tua dan guru. Dampak negatif terhadap perilaku sosial lainnya adalah pergaulan bebas dikalangan remaja, narkoba dan lain sebagainya. Sebagai contoh bentuk dehumanisasi dikalangan siswa dimana sering terjadi pertengkaran atau tawuran antar sekolah, pergaulan bebas di kalangan siswa SMP dan SMA, maraknya pornografi dan porno aksi yang dilakukan oleh siswa, dan lain sebagainya.

Salah satu jalan untuk menghambat proses dehumanisasi akibat dampak negatif laju perubahan sosial adalah melalui program pendidikan. Pendidikan sebagai upaya memanusiakan manusia (humanisasi) pada dasarnya adalah usaha mengembangkan kemampuan dan potensi individu, sehingga dapat hidup secara optimal, baik sebagai pribadi maupunsebagai anggota masyarakat, serta memiliki nilai-nilai moral dan sosial sebagai pedoman hidup. Dengan kata lain, pendidikan merupakan faktor utama dalam pembentukan pribadi manusia.

Pendidikan agama yang diselenggarakan di sekolah-sekolah mengemban tugas mewujudkan peradaban bangsa yang beriman, bertaqwa, berakhlak mulia cerdas, kreatif serta menjadi warga negara yang demokratis dan bertanggung jawab adalah melalui pendidikan Agama baik di sekolah, lingkungan keluarga, dan di masyarakat. Hal ini dikarenakan agama memiliki peran yang amat penting dalam kehidupan umat manusia. Agama menjadi pemandu dalam upaya mewujudkan suatu kehidupan yang bermakna, damai dan bermartabat. Menyadari betapa pentingnya peran agama bagi kehidupan umat manusia maka internalisasi nilai-nilai agama dalam kehidupan setiap pribadi menjadi sebuah keniscayaan, yang ditempuh melalui pendidikan baik pendidikan di lingkungan keluarga, sekolah maupun masyarakat.

Pendidikan secara ideal merupakan usaha untuk memproses seseorang agar memiliki kompetensi dalam bidang tertentu danjuga sekaligus sebagai proses humanisasi. Humanisasi yang dimaksud adalah upaya memanusiakan manusia atau dengan kata lain memproses manusia agar memiliki nilai toleransi, kejujuran, religiusitas, cinta damai dan kepedulian sosial. Memproses manusia menjadi berkompeten melalui pendidikan saja tanpa melakukan proses humanisasi (menanamkan nilai-nilai kemanusiaan) ibarat berjalan dengan kaki pincang. Pendidikan pincang, seperti tersebut di atas sama dengan melahirkan generasi-generasi muda yang unggul dalam bidang ilmu pengetahuan tetapi egois, tidak toleran, tidak jujur dalam persaingan dan tidak tumbuh rasa kepedulian sosialnya.

Sekolah Menengah Tingkat Atas (SMA) di bawah yayasan keagamaan merupakan lembaga pendidikan yang kepemilikannya dimiliki oleh lembaga-lembaga sosial keagamaan yang mempunyai visi dan misi sesuai dengan agama yang dianutnya. Namun demikian, berdasarkan UU Sisdiknas No 20 tahun 2003 mewajibkan setiap lembaga pendidikan memberikan fasilitas pendidikan agama bagi setiap peserta didik sesuai dengan keyakinannya. Oleh karena itu, secara ideal maka SMA-SMA di bawah yayasan keagamaan harus mampu 
menciptakan iklim keagamaan melalui program sekolahnya. Iklim keagamaan tersebut biasanya meliputi tata tertib dan keteladanan.

Berdasarkan latar belakang di atas, timbul pertanyaan apakah implementasi pendidikan agama di sekolah umum dibawah yayasan keagamaan selama ini mampu mempengaruhi perilaku keagamaan dan karakter peserta didik. Oleh karena itu penelitian ini bermaksud mengukur pengaruh implementasi pendidikan agama di sekolah umum terhadap perilaku keagamaan peserta didik usia SMA. Sekolahsekolah yang dimaksud adalah SMA/SMK di bawah yayasan keagamaan di Propinsi Kalimantan Tengah.

Berdasarkan paparan permasalahan diatas, studi ini difokuskan tentang bagaimana implementasi kurikulum pendidikan agama yang selama ini diterapkan pada sekolah di bawah yayasan keagamaan?; Adakah pengaruh implementasi pendidikan agama terhadap perilaku keagamaan peserta didik SMA pada sekolah di bawah yayasan keagamaan dilihat dari aspek religiusitas, kejujuran, toleransi, cinta damai dan kepedulian sosial?; dan Bagaimanakah idealnya implementasi pendidikan agama di sekolah umum di bawah yayasan keagamaan?

\section{Kerangka Konseptual}

\section{Implementasi Pendidikan Agama}

Pendidikan berarti segala usaha orang dewasa dalam pergaulan dengan anakanak untuk memimpin perkembangan jasmani dan rohaninya ke arah ke-dewasaan. ${ }^{1}$ Pendidikan merupakan sebuah usaha yang secara sadar dilakukan mulai dari komunitas manusia terkecil seperti

${ }^{1}$ Ramayulis, 2004. Ilmu Pendidikan Islam, Jakarta; Kalam Mulia, Cet ke-4, h. 14 keluarga, masyarakat, sampai dengan pemerintah melalui kegiatan bimbingan, pengajaran, dan latihan, yang berlangsung di sekolah dan di luar sekolah sepanjang hayat, demi mempersiapkan peserta didik agar dapat memainkan peranan dalam berbagai lingkungan hidup secara tepat di masa yang akan datang. Pendidikan adalah pengalaman-pengalaman belajar terprogram dalam bentuk pendidikan formal dan non formal, dan informal di sekolah, dan di luar sekolah, yang berlangsung seumur hidup yang bertujuan optimalisasi pertimbangan kemampuan-kemampuan individu, agar di kemudian hari dapat memainkan peranan hidup secara tepat. ${ }^{2}$

Sebagai sebuah bentuk kegiatan manusia dalam kehidupannya, pendidikan menempatkan tujuan sebagai sesuatu yang hendak dicapai. Tujuan pendidikan dapat bersifat abstrak sampai rumusanrumusan yang dibentuk secara khusus untuk memudahkan pencapaian tujuan yang lebih tinggi. Hal tersebut dikarenakan pendidikan merupakan bimbingan terhadap perkembangan manusia menuju ke arah cita-cita tertentu, maka yang merupakan masalah pokok bagi pendidikan adalah memilih arah atau tujuan yang akan dicapai.

Terkait dengan pendidikan agama, dalam Undang-Undang Sistem Pendidikan Nasional No. 20 tahun 2003 pasal 37 ayat (1) ditegaskan bahwa isi kurikulum pendidikan dasar dan menengah wajib memuat, antara lain pendidikan agama. ${ }^{3}$ Pendidikan agama dimaksudkan untuk membentuk peserta didik menjadi manusia yang beriman dan bertakwa kepada Tuhan dan berakhlak mulia serta peningkatan potensi spiritual. Akhlak

${ }^{2}$ Redja, Mudiyaharjo. 2002. Pengantar Pendidikan: Sebuah Studi Awal Tentang Dasar-dasar Pendidikan pada Umumnya dan Pendididkan di Indonesia, Cet ke-2, Jakarta : PT Raja Grafindo Persada, h. 11

${ }^{3}$ Undang Undang Nomor 20 Tahun 2003 tentang Sistem Pendidikan Nasional. 
mulia mencakup etika, budi pekerti, dan moral sebagai perwujudan dari pendidikan agama. Peningkatan potensi spiritual mencakup pengenalan, pemahaman, dan penanaman nilai-nilai keagamaan, serta pengamalan nilai-nilai tersebut dalam kehidupan individual ataupun kolektif kemasyarakatan.

Secara ideal kurikulum pendidikan agama setidaknya harus mampu memproses peserta didik agar memiliki perilaku keagamaan seperti dalam aspek religiusitas, kejujuran, toleransi, cinta damai dan kepedulian sosial. Perilaku keagamaan adalah segala bentuk amal perbuatan, ucapan, pikiran dan keikhlasan seseorang sebagai bentuk ibadah. Perilaku-perilaku ini antara lain dibentuk dari pemberian pendidikan agama di sekolah.

Pelaksanaan pendidikan agama di sekolah berbasis keagamaan memberikan dampak perilaku keagamaan kepada peserta didik. Perilaku keagamaan peserta didik tersebut berbeda-beda, hal ini disebabkan antara lain: 1) secara raw input, peserta didik ada yang berasal dari sekolah umum dan ada pula peserta didik yang berasal dari sekolah berbasis keagamaan; 2) secara lingkungan, terdapat sekolah yang menambah jam pelajaran pendidikan agama. Jam pelajaran pendidikan agama yang hanya dua jam dianggap oleh sekolah masih kurang, sehingga beberapa sekolah khususnya yang berada di bawah yayasan keagamaan memberikan tambahan pembelajaran pendidikan agama, baik secara formal maupun dalam kegiatan ekstra kurikuler; dan 3) peserta didik memperoleh tambahan pelajaran pendidikan agama di luar sekolah. Tambahan pelajaran pendidikan agama tersebut diperoleh siswa antara lain melalui kegiatan kuliah minggu pagi dan privat mengaji bagi siswa yang beragama Islam, kebaktian dan peribadatan gereja bagi peserta didik beragama Kristen maupun
Katolik, kegiatan keagamaan Hindu bagi peserta didik beragama Hindu, kegiatan Vihara bagi yang beragama Buddha, dan kegiatan Klenteng bagi peserta didik beragama Khonghucu.

\section{Perilaku Keagamaan}

Aspek keagamaan atau religiusitas, sebagaimana dikutip dari Paloutzian \& Park religiusitas adalah sebagai perasaan tindakan, dan pengalaman individual, secara jauh memahami diri mereka, untuk tetap berhubungan dengan apapun yang mereka anggap sebagai Tuhan. ${ }^{4}$ Aspek kejujuran, dimana agama apapun selalu mengajarkan manusia untuk selalu berbuat jujur. Kejujuran merupakan perilaku yang didasarkan pada upaya menjadikan dirinya sebagai orang yang selalu dapat dipercaya dalam perkataan, tindakan, dan pekerjaan. Aspek toleransi, dalam Kamus Umum Bahasa Indonesia, toleransi berasal dari kata "toleran" (Inggris: tolerance; Arab: tasamuh) yang berarti batas ukur untuk penambahan atau pengurangan yang masih diperbolehkan. Secara etimologi, toleransi adalah kesabaran, ketahanan emosional, dan kelapangan dada. Toleransi beragama adalah ialah sikap sabar dan menahan diri untuk tidak mengganggu dan tidak melecehkan agama atau sistem keyakinan dan ibadah penganut agama-agama lain. Aspek cinta damai berasal dari kata cinta dan damai, cinta dapat didefinisikan sebagai yaitu sikap, perkataan, dan tindakan yang menyebabkan orang lain merasa senang dan aman atas kehadiran dirinya. Menurut Erich Fromm dalam The Art of Loving (1996) ada empat syarat untuk mewujudkan cinta yaitu: perasaan, pengenalan, perhatian, dan

${ }^{4}$ Paloutzion, Raymond F \& Crytal L Park. 2005. Handbook of Psychology of Religion and Spirituality, New York : Guildford press. 
saling menghormati. ${ }^{5}$ Aspek peduli sosial, kata peduli memiliki makna mengindahkan atau memperhatikan, sedangkan sosial mengandung makna suka memperhatikan kepentingan umum, suka menolong, menderma dan sebagainya.

Beberapa aspek-aspek perilaku keagaman tersebut sebenarnya telah ada pada nilai-nilai agama sebagai petunjuk hidup umat manusia. Sudah semestinya pendidikan agama di sekolah mencakup semua aspek perilaku keagaman tersebut. Namun demikian, pembentukan perilaku keagamaan tidak terjadi dengan sendirinya. Pembentukan keagamaan senantiasa berlangsung dalam interaksi manusia dan berkenaan dengan objek tertentu. Sehingga perilaku itu dapat dipelajari dan dapat berubah sesuai dengan objek tertentu. Ada kemungkinan muncul perilaku yang positif dan negatif.

Pendidikan agama merupakan sumber spirit bagi siswa dalam bertingkah laku. Sehingga pendidikan agama di sekolah bisa menjadi dasar dalam pembentukan ahlaq siswa tanpa mengesampingkan pendidikan agama di luar sekolah. Adapun fungsi pendidikan agama di sekolah adalah sebagai berikut: $\left.{ }^{6} 1\right)$. Pengembangan potensi, kompetensi, keimanan dan ketakwaan kepada Tuhan YME serta akhlak mulia peserta didik seoptimal mungkin, yang telah dilakukan dalam lingkungan keluarga. Dengan demikian, sekolah berfungsi untuk menumbuhkembangkan lebih lanjut dalam diri anak melalui bimbingan, pengajaran dan pelatihan agar keimanan dan ketaqwaan tersebut dapat berkembang secara optimal sesuai dengan tingkat perkembangannya; 2). Penanaman nilai sebagai pedoman

${ }^{5}$ Gunadarma University Library : http://library. gunadarma.ac.id diakses 16 Januari 2012.

${ }^{6}$ Nurcholis Majid dan Dian Andayani. 2004. Pendidikan Agama Islam Berbasis Kompetensi. Bandung: PT Remaja Rosdakarya, h. 134-135) hidup untuk mencari kebahagiaan dunia dan akhirat; 3). Penyesuaian mental peserta didik terhadap lingkungan fisik dan sosial melalui pendidikan agama; 4). Perbaikan, yaitu memperbaiki kesalahankesalahan, kekurangan-kekurangan dan kelemahan-kelemahan peseta didik dalam keyakinan, pemahaman dan pengalaman ajaran dalam kehidupan sehari-hari; 5). Pencegahan terhadap hal-hal negatif dari lingkungannya atau dari budaya lain yang dapat membahayakan dirinya dan menghambat perkembangannya menuju manusia Indonesia seutuhnya; 6). Pengajaran ilmu pengetahuan keagamaan secara umum (alam nyata dan non-nyata), sistem dan fungsionalnya; 7). Menyalurkan anak-anak yang memiliki bakat khusus di bidang agama agar bakat tersebut dapat dimanfaatkan untuk dirinya dan bagi orang lain.

Penelitian sejenis yang pernah dilakukan seperti yang berjudul Pengaruh Pendidikan Agama Terhadap Perilaku Sosial Siswa SMU studi kasus di SMA Negeri III Salatiga, menghasilkan temuan bahwa pendidikan agama di SMA berpengaruh terhadap perilaku sosial siswa SMU (Litbang Agama Semarang, 2004). Yang membedakan dengan penelitian yang dilakukan adalah pada penelitian Wahab hanya mengambil sampel dari pengaruh pendidikan agama Islam pada sekolah negeri, sedangkan penelitian yang akan dilakukan pengambilan sampel tidak hanya pada mata pelajaran agama Islam saja tetapi juga mengambil sampel dari beberapa agama pada sekolah-sekolah yang berbasis pada yayasan keagamaan. ${ }^{7}$

Listia, dan kawan-kawan dalam Problematika Pendidikan Agama di Sekolah yang merupakan hasil penelitian tentang

7 Wahab. 2004. Pengaruh Pendidikan Agama Terhadap Perilaku Sosial Siswa SMU : Studi Kasus di SMA Negeri III Salatiga, Balai Litbang Agama Semarang, Semarang. 
pendidikan agama di kota Yogyakarta tahun 2004 - 2006, menghasilkan sebuah rekomendasi tentang pembaharuan pendidikan agama di sekolah umum yaitu pada level praktek pendidikan agama, faktor penting yang perlu untuk dicermati adalah adanya kebutuhan siswa yang sering kali tidak terjawab oleh materi-materi yang disiapkan oleh kurikulum yang disusun oleh pusatkekuasaan (negaramelalui departemen pendidikan). Metode yang menggurui dan menganggap rendah kemampuan siswa juga sangat kontra produktif dengan keberhasilan belajar. Guru-guru yang mengampu pendidikan agama secara umum sering tidak ambil pusing dengan kebutuhan siswa. Mengingat masyarakat Indonesia sebagian besar masih merasa optimis dengan peran pendidikan agama di sekolah, maka dilakukan pengkajian untuk pembaharuan pendidikan agama, khususnya dalam segi materi pembelajaran, metode belajar dan pemberdayaan guru agar lebih mampu menjadi pendidik yang kreatif memfasilitasi perkembangan kemampuan siswa dalam mengekspresikan iman dan kepercayaan untukm menjawab tantangan para siswa. ${ }^{8}$

Kerangka berpikir dalam penelitian ini yaitu tujuan akhir dari implementasi pendidikan agama di sekolah. Tujuan akhirnya adalah pembentukan perilaku keagamaan peserta didik agar memiliki jiwa agama. Artinya, pembelajaran agama di sekolah mampu menumbuhkan karakter-karakter agama dalam kehidupan sehari-hari baik di sekolah, keluarga dan masyarakat. Pertanyaannya adalah sejauh manakah pengaruh implementasi pendidikan agama di SMA terhadap perilaku keagamaan peserta didiknya dilihat dari aspek religiusitas, kejujuran, toleransi, cinta damai dan peduli sosial.

${ }^{8}$ Listia, dkk, 2007, Problematika Pendidikan Agama di Sekolah, Yogyakarta: Institut Dian/Interfidei,
Bila digambarkan sebagai berikut :

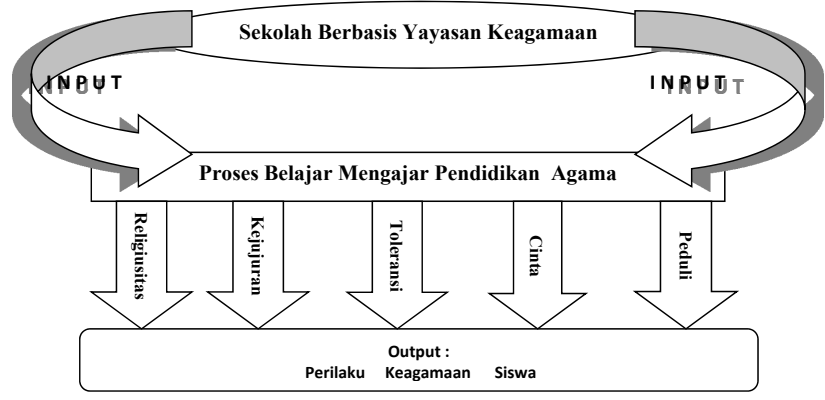

Dengan demikian, yang dimaksudkan dalam penelitian ini terhadap konsep: 1) implementasi adalah proses untuk memastikan terlaksananya suatu kebijakan dan tercapainya kebijakan tersebut. Impelementasi juga dimaksudkan menyediakan sarana untuk membuat sesuatu dan memberikan hasil yang bersifat praktis terhadap sesama. Van Meter dalam Subarsono (2006:100) mengartikan implementasi sebagai tindakan-tindakan oleh individu publik dan swasta (atau kelompok) yang diarahkan pada prestasi tujuan yang ditetapkan dalam keputusan kebijakan sebelumnya; 2) pendidikan agama adalah meliputi pendidikan agama Islam, Kristen, Katholik, Hindu, Buddha, dan Khonghucu; 2) sekolah di bawah yayasan keagamaan yang dimaksud adalah sekolahsekolah yang pengelolaannya di bawah yayasan yang mengatasnamakan salah satu agama sebagai landasan visi misinya; 3) perilaku yang dimaksud adalah perilaku yang berhubungan dengan religiusitas, kejujuran, toleransi, disiplin, kerja keras, kreatif, mandiri, demokratis, rasa ingin tahu, semangat kebangsaan, cinta tanah air, menghargai prestasi, bersahabat, cinta damai, gemar membaca, peduli lingkungan, peduli sosial, dan tanggung jawab; dan 4) peserta didik yang dimaksud adalah peserta didik SMA yang bersekolah pada sekolah di bawah yayasan keagamaan. 


\section{METODOLOGI PENELITIAN}

Penelitian ini dilakukan pada sekolah yang pengelolaannya berada di bawah yayasan keagamaan di Kalimantan Tengah. Setelah dilakukan studi lapangan maka diperoleh dua sekolah, yaitu SMA Kristen Palangkaraya dan SMA Muhammadiyah 1 Palangkaraya. Alasan pemilihannya adalah berdasarkan bahwa kedua sekolah tersebut termasuk yayasan pendidikan keagamaan yang besar di kota Palangka Raya.

Penelitian ini menggunakan pendekatan mixed method antara metode kuantitatif dan kualitatif. Metode kuantitatif digunakan untuk mengukur pengaruh implementasi pendidikan agama (sebagai variabel independen) terhadap perilaku keagamaan peserta didik (sebagai variabel dependen) pada SMA di bawah yayasan keagamaan. Tehnik pengumpulan datanya dengan menggunakan angket yang diisi oleh para responden. Sebelumnya melakukan uji instrumen yang dibagikan kepada sampel penelitian secara terbatas, yang tujuannya untuk mengetahui apakah pertanyaanpertanyaan yang ada dalam angket mudah dimengerti baik secara bahasa maupun isi. Teknik pengambilan sampel yang digunakan dalam penelitian ini adalah dengan teknik Multistage Random Sampling, yakni pengambilan sampel bertahap dan secara acak dari jumlah populasi. Adapun jumlah sampel dalam penelitian ini sebanyak 125 orang peserta didik.

Angket dilakukan untuk mengukur pengaruh pendidikan agama terhadap perilaku keagamaan peserta didik SMA di bawah yayasan keagamaan. Dalam angket telah ditentukan indikator-indikator yang di dalamnya berisi daftar pertanyaan untuk mengukur pengaruh pendidikan agama terhadap perilaku keagamaan peserta didik. Aspek aspek yang diukur meliputi religuisitas, kejujuran, toleransi, cinta damai, dan kepedulian sosial.
Nilaireligiusitasterkait dengan sikap dan perilaku yang patuh dalam melaksanakan ajaran agama yang dianutnya, toleran terhadap pelaksanaan ibadah agama lain, serta hidup rukun dengan pemeluk agama lain.

Nilai kejujuran terkait dengan perilaku yang didasarkan pada upaya menjadikan dirinya sebagai orang yang selalu dapat dipercaya dalam perkataan, tindakan, dan pekerjaan.

Nilai toleransi terkait dengan sikap dan tindakan yang menghargai perbedaan agama, suku, etnis, pendapat, sikap, dan tindakan orang lain yang berbeda dari dirinya.

Cinta damai, yaitu sikap, perkataan, dan tindakan yang menyebabkan orang lain merasa senang dan aman atas kehadiran dirinya.

Peduli sosial, yaitu sikap dan tindakan yang selalu ingin memberi bantuan pada orang lain dan masyarakat yang membutuhkan. ${ }^{9}$

Validasi instrumen dalam penelitian ini menggunakan validitas teoretik dan empiris. Validitas teoretik dilakukan dengan validitas logis dan validitas muka. Validitas logis yang dilakukan dalam penelitian ini adalah validitas isi dan validitas muka. Pengujian validitas isi dan validitas muka dilakukan dengan meminta pertimbangan pada 7 orang penimbang yang kompeten dibidangnya, yakni 4 orang akademisi dan 3 orang peneliti. Semua penimbang diminta menganalisis seluruh instrumen tes yang digunakan dalam penelitian ini. Validitas isi ini didasarkan pada: a) kesesuaian antara pernyataan dalam angket dengan kurikulum; b) kesesuaian antara butir statemen

${ }^{9} \mathrm{Ke}-18$ indikator perilaku keagamaan peserta didik tersebut di atas diadopsi dari indikator karakter Bangsa yang disusun oleh Badan litbang Kementerian Pendidikan Nasional 
dengan tingkat perkembangan siswa, dan c) kebenaran materi atau konsep dari pernyataan yang disusun. Untuk mengukur validitas muka para penimbang diminta menganalisis instrumen berdasarkan a) kejelasan instrument dari aspek bahasa; b) kejelasan sajian; dan c) tata penulisan.

Validitas empiris dilakukan dengan uji coba Instrumen kepada responden siswa SMA pada populasi diluar anggota sampel. Validitas empiris dilakukan dengan validitas internal dengan cara mengkorelasikan setiap skor butir dengan skor total. Seluruh data yang diperoleh dari responden sebelum diuji menggunakan analisis regresi terlebih dahulu diuji apakah item-item yang terdapat dalam kuesioner tersebut memenuhi syarat untuk dilakukan uji lanjut. Uji prasyarat tersebut adalah validitas dan reliabilitas instrumen.

Metode kualitatif dipergunakan untuk mengetahui penyebab pengaruh pendidikan agama terhadap perilaku keagamaan siswa yang dilihat dari aspek religiusitas, kejujuran, toleransi, cinta damai, dan peduli sosial. Selain itu metode kualitatif yang dipergunakan dalam penelitian ini digunakan untuk mencari format pendidikan agama yang ideal di sekolah di bawah yayasan keagaman. Tehnik pengumpulan datanya dengan wawancara mendalam (depth interview) terhadap informan atau narasumber kunci.

Selain itu, juga menggunakan tehnik pengumpulan data melalui focus group disussion (FGD) dilakukan dengan melibatkan pendidik, komite sekolah dan stake holders lainnya, yang tujuannya untuk mencari pokok-pokok persoalan yang dihadapi oleh pendidik dalam mengimplementasikan pendidikan agama di sekolah. Bahan FGD terdiri dari beberapa pertanyaan yang terdiri dari: Pertama, Implementasi pendidikan agama pada peserta didik SMA : a). Apakah kurikulum pendidikan agama yang ada saat ini mampu memproses peserta didik agar memiliki perilaku keagamaan pada aspek religiusitas, kejujuran, toleransi, cinta damai dan kepedulian sosial?, b). Apakah standar proses pendidikan agama yang ada sudah dilaksanakan dengan benar? kendalakendala apa saja yang dihadapi dalam penerapannya?, c). Apakah kurikulum pendidikan agama sudah dijalankan dengan benar di sekolah?, d). Program-program apa saja yang dilakukan pihak sekolah dalam pelaksanaannya dan bagaimana sistem evaluasinya?. Kedua, Perilaku keagamaan peserta didik SMA di bawah yayasan keagamaan. Bagaimana perilaku keagamaan peserta didik yang berkaitan dengan religiusitas, kejujuran, toleransi, cimta damai, dan kepedulian sosial?. Ketiga, Model ideal seperti apa yang diharapkan dalam implemetasi pendidikan keagamaan supaya dapat benar-benar membentuk kebiasaan dan perilaku keagamaan yang sesuai dengan ajaran agama?

\section{Hipotesis Penelitian}

Pertama, tidak terdapat pengaruh yang signifikan antara pendidikan agama di sekolah terhadap perilaku keagamaan peserta didik (Ho), Kedua, terdapat pengaruh yang signifikan antara implementasi pendidikan agama di sekolah terhadap perilaku keagamaan peserta didik (Ha)

\section{Uji Validitas}

Validitas empiris dilakukan dengan validitas internal dengan cara mengorelasikan setiap skor butir dengan skor total. Dari 40 item implementasi pendidikan agama di SMA dan 40 item perilaku keagamaan peserta didik, setelah melakukan pengambilan data pada 125 responden dan divalidasi, ada beberapa item yang gugur sebanyak 2 item pertanyaan pada implementasi pendidikan agama 
di SMA dan 4 item perilaku keagamaan peserta didik. Sehingga instrumen implementasi pendidikan agama berjumlah 38 buah pertanyaan, dan instrumen perilaku keagamaan peserta didik berjumlah 36 buah pertanyaan.

\section{Uji Reliabilitas}

Tabel 1. Uji reliabilitas instrumen variabel independen Reliability Statistiks

\begin{tabular}{|c|c|}
\hline Cronbach's Alpha & N of Items \\
\hline .884 & 38 \\
\hline
\end{tabular}

Dari tabel uji reliabilitas instrumen implementasi pendidikan agama (variabel independen) pada SMA dibawah yayasan keagamaan diketahui nilai Croncbach's Alpha sebesar 0,884. Nilai ini termasuk reliabel dan dalam kategori baik.

Tabel 2. Uji reliabilitas instrumen variabel dependen Reliability Statistiks

\begin{tabular}{|c|c|}
\hline Cronbach's Alpha & N of Items \\
\hline 899 & 36 \\
\hline
\end{tabular}

Sedangkan untuk variabel perilaku keagamaan (variabel dependen) pada SMA di bawah yayasan keagamaan, dari hasil perhitungan reliabilitas diperoleh nilai Croncbach's Alpha sebesar 0,899. Nilai ini termasuk reliabel dan dalam kategori baik.

\section{Uji Persyaratan Analisis}

Uji Linieritas dilakukan untuk mengetahui apakah dua variabel secara signifikan mempunyai hubungan linier atau tidak. Pada taraf konfiden level 95 \% (taraf kesalahan 5\%) dua buah variabel dikatakan mempunyai hubungan yang linier apabila nilai signifikansi linierity kurang dari 0,05.
Pada tabel anova (tabel 1) dapat diketahui signifikansi pada linieritas (linierity) sebesar 0,000. Karena nilai signifikansi hasil hitung kurang $0,05(0,000<0,05)$ maka dapat disimpulkan bahwa antara variabel implementasi pendidikan agama dan perilaku keagamaan peserta didik terdapat hubungan yang linier.

Tabel 3. Tabel Anova

\begin{tabular}{|l|l|l|r|}
\hline & & \multicolumn{1}{|c|}{$\begin{array}{c}\text { Sum of } \\
\text { Squares }\end{array}$} \\
\hline$Y * X$ & $\begin{array}{l}\text { Between } \\
\text { Groups }\end{array}$ & (Combined) & 14401.669 \\
\hline & & Linearity & 7459.956 \\
\hline & & $\begin{array}{l}\text { Deviation from } \\
\text { Linearity }\end{array}$ & 6941.713 \\
\hline & $\begin{array}{l}\text { Within } \\
\text { Groups }\end{array}$ & 7341.083 & 71 \\
\hline & Total & 21742.752 & 124 \\
\hline
\end{tabular}

Lanjutan...

\begin{tabular}{|r|r|r|r|}
\hline \multicolumn{1}{|c|}{ Df } & Mean Square & \multicolumn{1}{c|}{ F } & \multicolumn{1}{l|}{ Sig. } \\
\hline 53 & 271.730 & 2.628 & .000 \\
\hline 1 & 7459.956 & 72.150 & .000 \\
\hline 52 & 133.494 & 1.291 & .158 \\
\hline 103.396 & & & \\
\hline & & & \\
\hline
\end{tabular}

Uji Homogenitas untuk mengetahui apakah beberapa varian populasi data adalah sama atau tidak. Signifikansi yang digunakan untuk menyatakan data berasal dari populasi yang sama adalah alfa >0,05 . Hipotesis untuk menguji apakah data sampel homogen adalah H0: $\sigma 12=\sigma 22$ atau "kedua kelompok sampel tidak memiliki perbedaan variansi". Pada tabel Test of Homogeneity of Variances (tabel 2), dari hasil uji homogenitas sebagaimana pada tabel di atas diperoleh nilai signifikansi sebesar 0,130. Nilai signifikansi tersebut lebih besar dari 0,05 (tingkat kepercayaan $95 \%)$. Dengan demikian hipotesis nol yang berbunyi tidak ada perbedaan varian dalam populasi diterima. Dengan kata lain dapat 
dikatakan sampel data yang diperoleh dalam penelitian ini bersasal dari populasi yang sama.

Tabel 4. Test of Homogenity of Variances

\begin{tabular}{|c|c|c|c|}
\hline $\begin{array}{c}\text { Levene } \\
\text { Statistik }\end{array}$ & df1 & df2 & Sig. \\
\hline 1.376 & 32 & 75 & .130 \\
\hline
\end{tabular}

Uji Normalitas Data digunakan adalah uji one sampele kolmogorov smirnorv. Data dinyatakan berdistribusi normal apabila signifikansi hasil perhitungan lebih besar dari 0,05 , atau dengan kata lain tingkat kepercayaan data adalah $95 \%$. Dari hasil perhitungan uji normalitas pada tabel OneSample Kolmogorov-Smirnov Test (tabel 3) data dengan menggunakan alat uji kolmogororv sminorv $\mathrm{Z}$ diperoleh nilai alfa (Asymp.Sig. (2-tailed) sebesar 0,448 untuk variabel perilaku keagamaan dan 0,340 untuk variabel implementasi pendidikan agama di SMA yayasan keagamaan. Karena nilai signifikansi tersebut lebih besar dari 0,05 (5\%), maka sampel berasal dari distribusi normal.

Tabel 5. One-Sample KolmogorovSmirnov Test

\begin{tabular}{|l|l|r|r|}
\hline \multirow{2}{*}{} & & \multicolumn{1}{|c|}{$\begin{array}{c}\text { Implementasi } \\
\text { Pendidikan } \\
\text { Agama }\end{array}$} & $\begin{array}{c}\text { Perilaku } \\
\text { Siswa }\end{array}$ \\
\hline \multicolumn{2}{|c|}{$\mathrm{N}$} & 125 & 125 \\
\hline \multirow{2}{*}{$\begin{array}{l}\text { Normal } \\
\text { Parameters }\end{array}$} & Mean & 121.96 & 120.27 \\
\cline { 2 - 4 } & $\begin{array}{l}\text { Std. } \\
\text { Deviation }\end{array}$ & 15.163 & 13.242 \\
\hline $\begin{array}{l}\text { Most } \\
\text { Extreme } \\
\text { Differences }\end{array}$ & Absolute & .077 & .084 \\
\cline { 2 - 4 } & Positive & .047 & .052 \\
\cline { 2 - 4 } & Negative & -.077 & -.084 \\
\hline Kolmogorov-Smirnov Z & .861 & .940 \\
\hline Asymp. Sig. (2-tailed) & .448 & .340 \\
\hline
\end{tabular}

a. Test distribution is Normal

\section{HASIL DAN PEMBAHASAN}

Hipotesis yang digunakan dalam penelitian ini adalah:

$\mathrm{Ho}=$ tidak terdapat pengaruh yang signifikan antara pendidikan agama di sekolah terhadap perilaku keagamaan peserta didik. Sedangkan $\mathrm{Ha}=$ terdapat pengaruh yang signifikan antara implementasi pendidikan agama di sekolah terhadap perilaku keagamaan peserta didik.

\section{Tabel 6 : Correlation}

\begin{tabular}{|c|c|c|c|}
\hline & & $\begin{array}{c}\text { Implementasi } \\
\text { Pendidikan } \\
\text { Agama }\end{array}$ & $\begin{array}{c}\text { Perilaku } \\
\text { Siswa }\end{array}$ \\
\hline \multirow{3}{*}{$\begin{array}{l}\text { Implemen- } \\
\text { tasi } \\
\text { Pendidikan } \\
\text { Agama }\end{array}$} & $\begin{array}{l}\text { Pearson } \\
\text { Correlation }\end{array}$ & 1 & $.586^{* *}$ \\
\hline & $\begin{array}{c}\text { Sig. } \\
\text { (2-tailed) }\end{array}$ & & .000 \\
\hline & $\mathrm{N}$ & 125 & 125 \\
\hline \multirow{3}{*}{$\begin{array}{l}\text { Perilaku } \\
\text { Siswa }\end{array}$} & $\begin{array}{l}\text { Pearson } \\
\text { Correlation }\end{array}$ & $.586^{\star *}$ & 1 \\
\hline & $\begin{array}{c}\text { Sig. } \\
\text { (2-tailed) }\end{array}$ & .000 & \\
\hline & $\mathrm{N}$ & 125 & 125 \\
\hline
\end{tabular}

**. Correlation is significant at the 0.01 level (2-tailed).

Koefisien Korelasi merupakan salah satu analisis yang berfungsi untuk mengetahui ada dan tidaknya hubungan antara variabel terikat dan bebas. Disini untuk mengetahui ada tidaknya dan seberapa besar hubungan variabel implemetasi pendidikan agama dan perilaku keagamaan peserta didik. Dari tabel Correlation (tabel 4) diatas terlihat besar hubungan antara variabel implementasi pendidikan agama dan perilaku keagamaan peserta didik sebesar 0,586. Korelasi tersebut bersifat positif, yang mana menunjukan hubungan antara implementasi pendidikan agama dan perilaku keagamaan peserta didik searah. Maksudnya jika implementasi pendidikan agama besar atau semakin meningkat maka perilaku keagamaan peserta didik juga akan semakin besar atau meningkat. Dari nilai signifikansi di atas 
diperoleh angka sebesar 0,000 yang ternyata lebih kecil dari 0,05. Jika signifikansi hasil hitung lebih kecil dari 0,05 maka berarti terdapat hubungan yang signifikan antara variabel implementasi pendidikan agama dengan perilaku keagamaan peserta didik.

Uji Signifikansi Koefisien Korelasi berfungsi untuk melihat besarnya pengaruh variabel implementasi pendidikan agama di SMA yayasan keagamaan terhadap perilaku keagamaan peserta didiknya dapat digunakan uji t. Uji t digunakan untuk menguji signifikansi konstanta dan variabel implementasi pendidikan agama di SMA yayasan keagamaan yang digunakan sebagai prediktor untuk variabel perilaku keagamaan peserta didik. Diketahui t tabel n 125 dengan signifikansi 0,05 (1 tailed) sebesar 1,98 dan thitung $=8,015$ maka keputusannya adalah $t$ hitung $>t$ tabel. Dengan demikian Ho ditolak dan Ha diterima, yang artinya terdapat pengaruh antara implementasi pendidikan agama pada SMA dibawah yayasan keagamaan terhadap perilaku keagamaan siswa peserta didik.

Tabel 7 : Coefficients ${ }^{\mathrm{a}}$

\begin{tabular}{|c|c|c|}
\hline \multicolumn{2}{|c|}{$\begin{array}{c}\text { Unstandardized } \\
\text { Coefficients }\end{array}$} & $\begin{array}{c}\text { Standardized } \\
\text { Coefficients }\end{array}$ \\
\hline B & Std. Error & Beta \\
\hline 57.885 & 7.843 & \\
\hline .512 & .064 & .586 \\
\hline
\end{tabular}

Lanjutan...

\begin{tabular}{|c|c|c|c|}
\hline \multirow{2}{*}{$\mathbf{t}$} & \multirow{2}{*}{ Sig. } & \multicolumn{2}{|c|}{ Collinearity Statistiks } \\
\cline { 3 - 4 } & & Tolerance & VIF \\
\hline 7.380 & .000 & & \\
\hline 8.015 & .000 & 1.000 & 1.000 \\
\hline
\end{tabular}

Dependent Variabel: Perilaku Siswa

Persamaan Regresi, pada bagian ini menggambarkan persamaan regresi untuk mengetahui angka konstan, dan uji hipotesis signifikansi koefisien regresi. Dari tabel Coefficients $^{a}$ (tabel 5) diatas diperoleh nilai a (angka konstan) dari unstandarized coefficient sebesar 57.885. Angka ini berupa angka konstan yang mempunyai arti jika tidak ada tambahan satu indicator implementasi pendidikanagamadiSMAyayasankeagamaan maka perilaku keagamaan secara teori akan berkurang atau menurun sebesar 57.885. Sedangkan nilai $b$ adalah angka koefisien regresi. Dari tabel output koefisien regresi di atas diperoleh nilai koefisien regresi sebesar + 0.512 (positif). Angka tersebut mempunyai arti bahwa setiap penambahan 1 indikator implementasi pendidikan agama di SMA yayasan keagamaan maka perilaku keagamaan peserta didik akan semakin meningkat atau semakin baik sebesar 0.512. Namun sebaliknya jika koefisien regresiyang diperoleh nilai negatif ( - ) maka perilaku keagamaan peserta didik akan menurun sebesar angka tersebut. Oleh karena itu, maka persamaan regresinya dari $\mathrm{Y}=\mathrm{a}+\mathrm{bx}$, menjadi $Y=57.885+0.512 \mathrm{x}$.

Uji Keberartian Regresi, dari tabel anova menjelaskan apakah variasi nilai variabel bebas atau variabel independen dapat menjelaskan variasi nilai dependen dengan menggunakan besarnya nilai F. Dari tabel anova (tabel 1) diketahui $\mathrm{F}$ hitung adalah 2,628; sedangkan besarnya signifikansinya 0,000 . Signifikansi tabel ANOVA 0,000 lebih kecil dari 0,005; dengan demikian dalam hipotesisnya Ho ditolak dan Ha diterima. Dengan demikian variasi nilai variabel bebas atau variabel independen dapat menjelaskan variasi nilai dependen.

Koefisien Determinasi/Kontribusi dalam penelitian ini digunakan untuk menghitung besarnya pengaruh variabel implementasi pendidikan agama di SMA terhadap perilaku keagamaan peserta didiknya. Koefisien dihitung dengan cara melihat $\mathrm{r}^{2}$ (R Square). Dari hasil perhitungan pencarian koefisien determinasi di peroleh nilai $\mathrm{r}^{2}$ ( $\mathrm{R}$ Square) sebesar 0.343. Angka tersebut berarti bahwa sebesar $34.3 \%$ perilaku keagamaan peserta 
didik dapat dijelaskan oleh implementasi pendidikan agama. Sedangkan sisanya yaitu $65.7 \%$ harus dijelaskan oleh faktor yang lain diluar penelitian ini.

Terkait dengan pendidikan agama, dalam Undang-Undang Sistem Pendidikan Nasional No. 20 tahun 2003 pasal 37 ayat (1) ditegaskan bahwa isi kurikulum pendidikan dasar dan menengah wajib memuat, antara lain pendidikan agama (UUSPN No. 20 Tahun 2003), dan dalam pasal 30 ayat 2 menjelaskan bahwa pendidikan keagamaan berfungsi menyiapkan peserta didik menjadi anggota masyarakat yang memahami dan mengamalkan nilai-nilai ajaran agamanya dan/atau menjadi ahli ilmu agama. ${ }^{10}$ Pendidikan agama dimaksudkan untuk membentuk peserta didik menjadi manusia yang beriman dan bertakwa kepada Tuhan dan berakhlak mulia serta peningkatan potensi spiritual. Akhlak mulia mencakup etika, budi pekerti, dan moral sebagai perwujudan dari pendidikan agama. Peningkatan potensi spiritual mencakup pengenalan, pemahaman, dan penanaman nilai-nilai keagamaan, serta pengamalan nilai-nilai tersebut dalam kehidupan individual ataupun kolektif kemasyarakatan. Peningkatan potensi spiritual tersebut pada akhirnya bertujuan pada optimalisasi berbagai potensi yang dimiliki manusia yang aktualisasinya mencerminkan harkat dan martabatnya sebagai makhluk Tuhan.

Untuk memperdalam dan memperoleh penjelasan terkait dengan variabel lain yang mempengaruhi perilaku peserta didik itu maka ditempuh dengan melalui Forum Group Discussion (FGD) yang pesertanya terdiri dari para kepala sekolah, wakil kepala sekolah, guru agama, komite sekolah, yayasan, dan steakholder. Berdasarkan pembahasan dalam FGD itu dapat dipahami

\footnotetext{
${ }^{10}$ Undang Undang Sistem Pendidikan Nasional Tahun 2003
}

bahwa variabel lain yang mempengaruhi perilaku keagamaan peserta didik adalah lingkungan keluarga dan lembaga-lembaga keagamaan di luar sekolah.

FGD diadakan sebanyak dua kali, yang pertama dilaksanakan di SMA Kristen Palangka Raya, dan yang kedua dilaksanakan di SMA Muhammadiyah 1 Palangka Raya. Dari kedua pelaksanaan FGD tersebut dapat peneliti tarik beberapa hal penting dalam hubungan antara variabel Implementasi pendidikan agama pada SMA di bawah yayasan keagamaan dengan variabel perilaku keagamaan peserta didik yang bersekolah pada SMA di bawah yayasan keagamaan.

Dalam bidang kurikulum, dimana sekolah sudah melaksanakan kurikulum pendidikan agama didalam membentuk perilaku siswa dalam aspek religiusitas, kejujuran, toleransi, cinta damai, dan kepedulian sosial sudah sesuai dengan ketentuan yang ditetapkan oleh pemerintah. Walaupun di setiap sekolahan masih perlu penyesuaian sesuai dengan keadaan sekolah masing-masing. Misalnya yang tertuang dalam tata tertib yang sudah ditetapkan oleh pihak sekolah.

Pengembangan kurikulum muatan lokal dimaksudkan terutama untuk mengimbangi kelemahan-kelemahan pengembangan kurikulum sentralisasi, dan bertujuan agar peserta didik mencintai dan mengenal lingkungannya, serta mampu melestarikan dan mengembangkan sumber daya alam, kualitas sosial, dan kebudayaan regional, maupun pembangunan lokal sehingga peserta didik tidak terlepas dari akar sosial budaya lingkungannya. ${ }^{11}$

11 Joko Susilo, 2007, Kurikulum Tingkat Satuan Pendidikan Manajemen Pelaksanaan dan Kesiapan Sekolah Menyongsongnya, Yogyakarta : Pustaka Pelajar, Cetakan II, . 
Kendala-kendala yang dihadapi dalam implementasi pendidikan agana disekolah untuk membentuk perilaku keagamaan siswa, antara lain : 1) Minimnya jam pelajaran pendidikan agama yang hanya 2 jam pelajaran setiap minggunya; 2) Pembentukan perilaku siswa tidak hanya dipengaruhi oleh lingkungan sekolah khususnya pelajaran agama, tetapi juga dipengaruhi oleh faktor-faktor eksternal sekolah, misalnya lingkungan keluarga dan sekitarnya; 3) Terbatasnya pengetahuan tentang keagamaan bagi guru-guru bidang studi selain pendidikan agama. Padahal ini sangat diperlukan didalam membantu guru agama dalam pembentukan perilaku keagamaan siswa yang bagus; 4) Masalah sarana dan prasarana dalam kegaiatan pelajaran keagamaan; dan 5) Adanya perbedaan pemahaman antar pemeluk dalam agama tertentu.

Program-program implementasi pendidikan agama yang dilakukan di sekolah selain pendidikan agama dua jam pelajaran setiap minggunya antara lain : 1) kebaktian setiap pagi hari dimulai pukul 06.15 wib, berdoa bersama dikelas sebelum dan setelah selesai proses belajar, dan ibadah bulanan dengan mendatangkan pihak pendeta dari gereja; 2) Di SMA Muhammadiyah program hariannya berupa salat luhur berjamaah di masjid dan ceramah keagamaan yang disampaikan oleh guru-guru, tadarus $\mathrm{Al}$ Qur'an setiap pagi sebelum jam pelajaran jam pertama dimulai, berdoa bersama dikelas sebelum dan setelah selesai proses belajar, kegiatan pengajian bulanan yang dikoordinir oleh Osis, dan ada program hafalan surat-surat pendek kitab suci Al Qur'an diluar jam pelajaran agama; 3) Siswa dianjurkan membuat catatan khusus tentang kegiatan keagamaan diluar sekolah. Misalnya dalam kegiatan di gereja siswa diwajibkan mengerti liturki (langkahlangkah yang dilakukan dalam peribadatan di gereja) peribadatan di gereja tersebut; dan 4) Kedua sekolah juga sudah melaksanakan kegaiatan visualisasi dalam bentuk tulisan tentang ajakan untuk jujur, berpakaian rapi, meningkatkan ketakwaan, dan lain-lain.

Perilaku keagamaan peserta didik yang berkaitan dengan religiusitas, kejujuran, toleransi, cinta damai, dan kepedulian sosial terlihat pada sikap siswa antara lain : 1) Perilaku keagamaan peserta didik yang berkaitan dengan religiusitas terlihat dengan keyakinan siswa terhadap Tuhan beserta ciptaanNya; 2) Perilaku keagamaaan siswa terkait dengan kejujuran terlihat dari para siswa yang membeli dikantin sekolah tidak pernah curang, kalau para siswa menemukan barang yang hilang dilingkungan sekolah, maka diwajibkan menyerahkan kepada pihak sekolah untuk diumumkan; 3) Perilaku keagamaaan siswa terkait dengan toleransi terlihat dari para siswa menghormati sesama teman maupun guru, bila bertemu dengan teman atau guru mereka memberikan salam. Ada sebuah falsafah tentang hidup rukun antar sesama manusia walau berbeda keyakinan. Falsafah tersebut bernama huma betang, dimana dalam sebuah rumah besar yang didalamnya terdapat beberapa kepala keluarga dengan berbagai agama yang ada didalamnya dan hidup rukun berdampingan; 4) Perilaku keagamaaan siswa terkait dengan kepedulian sosial terlihat dari para siswa yang berpartisipasi apabila temannya yang sedang mengalami musibah, misalnya menjenguk teman atau orang tua yang sedang sakit, keluarga yang meninggal, dan lain-lain; 5) Perilaku keagamaaan siswa terkait dengan cinta damai terlihat dari para siswa di kedua sekolah tersebut tidak pernah terjadi perkelahian antar pelajar baik secara perseorangan maupun secara tawuran antar sekolah. Hal ini juga bisa terbentuk karena sikap toleransi yang tinggi dikalangan siswa kedua sekolah tersebut. 
Dalam rangka mencari bentuk ideal dalam implementasi pendidikan agama, antara lain : 1) Perlu dilaksanakan pengembangan kurikulum dari pemerintah dengan muatan lokal yang disesuaikan dengan kebutuhan sekolah; 2) Mengadakan kegiatan keagamaan yang bersifat harian, mingguan, dan bulanan, serta meminimalisir kendala-kendala dalam pelaksanaannya; 3) Menerapkan tujuan implementasi pendidikan agama dalam dua kerangka besar, yaitu kesalehan spiritual (aspek religiusitas) dan kesalehan sosial (misal aspek toleransi, kejujuran, dan kepedulian sosial cinta damai); 4) Mensinergikan seluruh mata pelajaran lainnya dalam membentuk perilaku peserta didik; dan perlu menyelenggarakan pendidikan etika atau budi pekerti secara khusus, agar dapat menunjang pendidikan agama yang masih banyak kelemahannya.

Model ideal implemetasi pendidikan agama yang diharapkan sesuai hasil FGD dapat digambarkan sebagai berikut :

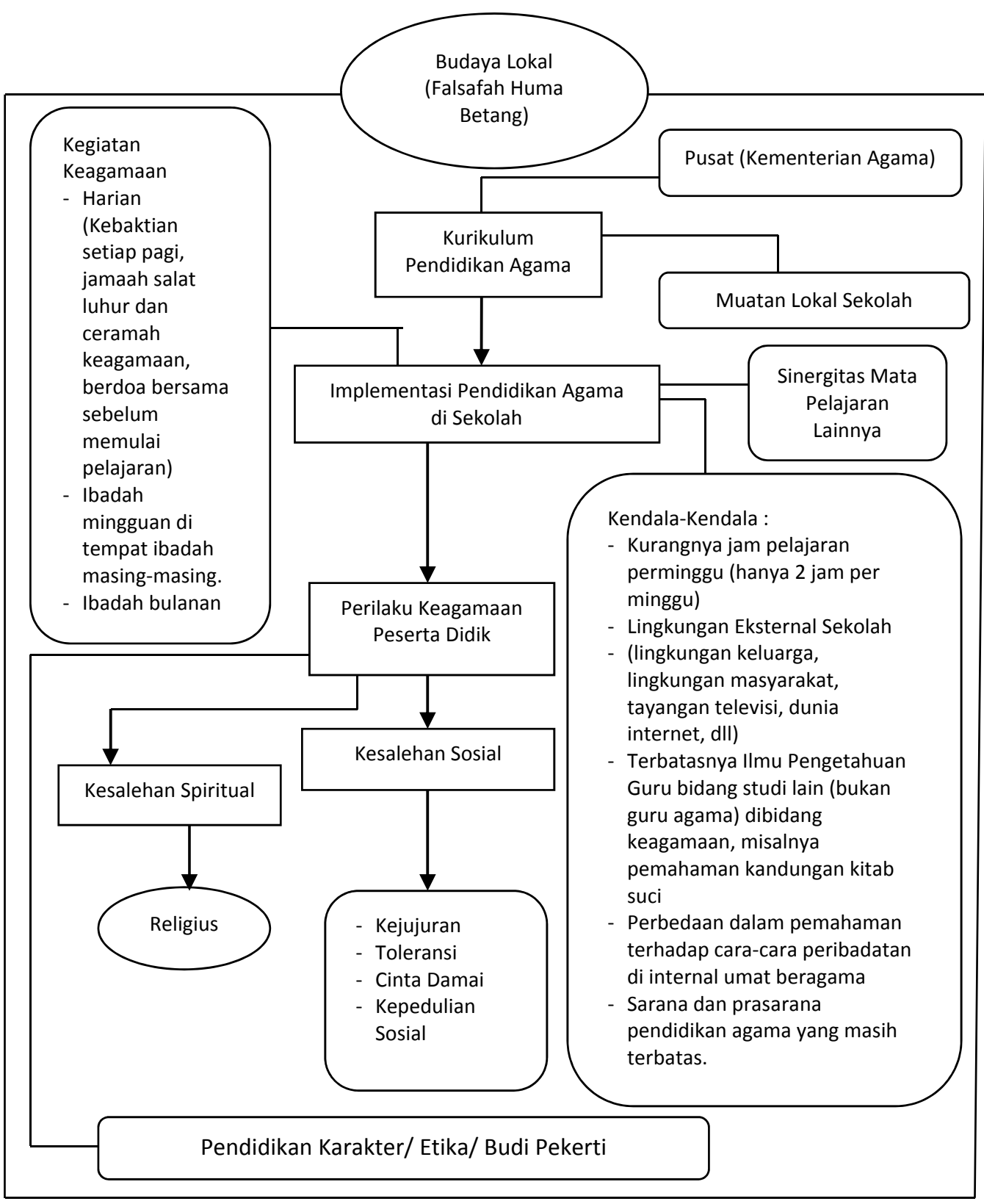




\section{PENUTUP}

\section{Kesimpulan}

Ada hubungan antara variabel Implementasi pendidikan agama pada SMA di bawah yayasan keagamaan dengan variabel perilaku keagamaan peserta didik yang bersekolah pada SMA di bawah yayasan keagamaan, yaitu sebesar 34,3\%, yang berarti sisanya sebesar 65,7 harus dijelaskan oleh faktor yang lain diluar jangkauan penelitian.

Didalam mengimplementasikan kurikulum pendidikan agama pihak sekolah sudah sesuai dengan ketentuan yang berlaku, masih mengadakan penyesuianpenyesuaian sesuai dengan kebutuhannya sebagai sekolah berbasis keagamaan. Secara umum menyelenggarakan hanya 2 jam pelajaran seminggu, sehingga perlu bantuan dari mata pelajaran yang lainnya dalam membentuk perilaku peserta didik yang baik.

Dalam rangka mencari bentuk ideal dalam implementasi pendidikan agama, maka perlu dilaksanakan Kurikulum yang berbasis dari pemerintah dan muatan lokal yang disesuaikan dengan kebutuhan masing-masing sekolah; Mengadakan kegiatan keagamaan yang bersifat harian, mingguan, dan bulanan, serta meminimalisir kendala-kendala yang menjadi penghambat dalam pelaksanaannya; Menerapkan tujuan implementasi pendidikan agama dalam dua kerangka besar, yaitu kesalehan spiritual (aspek religiusitas) dan kesalehan sosial (misal aspek toleransi); Mensinergikan seluruh mata pelajaran lainnya dalam membentuk perilaku peserta didik; Perlunya menyelenggarakan pendidikan etika atau budi pekerti secara khusus tersendiri, agar dapat menunjang pendidikan agama yang masih banyak kelemahannya.

\section{DAFTAR PUSTAKA}

Gunadarma University Library : http:// library.gunadarma.ac.id diakses 16 Januari 2012.

Ke-18 indikator perilaku keagamaan peserta didik tersebut di atas diadopsi indikator karakter Bangsa yang disusun oleh Badan litbang Kementerian Pendidikan Nasional

Listia, dkk, (2007) : Problematika Pendidikan Agama di Sekolah, Institut Dian/ Interfidei, Yogyakarta.

Majid, Nurcholis, dan Dian Andayani, (2004) : Pendidikan Agama Islam Berbasis Kompetensi, Bandung: PT Remaja Rosdakarya, h. 134-135)

Mudiyaharjo, Redja, (2002) : Pengantar Pendidikan: Sebuah Studi Awal Tentang Dasar-dasar Pendidikan pada Umumnya dan Pendididkan di Indonesia, Cet ke-2, PT Raja Grafindo Persada Jakarta

Paloutzion, Raymond F \& Crytal L Park, (2005): Handbook of Psychology of religion and spirituality, Guildford press, New York.

Ramayulis, (2004) : Ilmu Pendidikan Islam. Jakarta; Kalam Mulia, Cet ke-4, h. 14

Susilo, Joko, (2007): Kurikulum Tingkat Satuan Pendidikan Manajemen Pelaksanaan dan Kesiapan Sekolah Menyongsongnya, Pustaka Pelajar, Cetakan II, Yogyakarta.

Undang Undang Sistem Pendidikan Nasional Tahun 2003

Undang Undang Sistem Pendidikan Nasional Tahun 2003.

Wahab, (2004) : pengaruh pendidikan agama terhadap perilaku sosial siswa SMU: Studi Kasus di SMA Negeri III Salatiga, Balai Litbang Agama Semarang, Semarang. 